\title{
Pheromone Production, Attraction, and Interspecific Inhibition among Four Species of Ips Bark Beetles in the Southeastern USA
}

\author{
Göran Birgersson, ${ }^{1}$ Mark J. Dalusky, ${ }^{2}$ Karl E. Espelie, ${ }^{2}$ and C. Wayne Berisford ${ }^{2}$ \\ ${ }^{1}$ Division of Chemical Ecology, Department of Plant Protection Biology, Swedish University of Agricultural Sciences, P.O. Box 102, \\ 23053 Alnarp, Sweden \\ ${ }^{2}$ Department of Entomology, University of Georgia, Athens, GA 30602, USA
}

Correspondence should be addressed to Göran Birgersson, goeran.birgersson@slu.se

Received 9 December 2011; Accepted 26 January 2012

Academic Editor: John A. Byers

Copyright (C) 2012 Göran Birgersson et al. This is an open access article distributed under the Creative Commons Attribution License, which permits unrestricted use, distribution, and reproduction in any medium, provided the original work is properly cited.

Hindgut volatiles from attacking, unmated males of Ips avulsus, I. calligraphus, I. grandicollis, and I. pini were analyzed by combined gas chromatography and mass spectrometry. Based on the quantitative identifications of hindguts and subsequent individual aerations, baits were formulated and a combined species-specific subtractive field bioassay was set up for the four bark beetle species. The bioassays were subtractive for the compounds identified in the hindgut analysis of each species, and volatiles identified in sympatric species were added as potential inhibitors alone and in combination. The trap catches from this bioassay revealed strong interspecific inhibition. The subtractive assays showed that I. grandicollis and I. calligraphus share (-)-(4S)-cis-verbenol as one pheromone component, while their second, synergistic pheromone component, $(-)-(S)$-ipsenol in I. grandicollis and ( \pm )ipsdienol in I. calligraphus, acts as an interspecific inhibitor to the other species. I. avulsus and I. pini were found to have very similar production of hindgut volatiles, and both use ipsdienol and lanierone as synergistic pheromone components. No beetleproduced interspecific inhibitor was identified between these two species. Lanierone was found to be an interspecific inhibitor for both I. calligraphus and I. grandicollis.

\section{Introduction}

The bark beetle genus of Ips is circumpolar, and different species range all over the northern hemisphere. In North America, there are 25 species of Ips [1], and of these, four species are indigenous to the Southeastern USA [2-4]. Ips calligraphus (Germar) has its range predominantly in the coastal plain, I. pini (Say) is limited to the Appalachian mountain range, while I. avulsus (Eichhoff) and I. grandicollis (Eichhoff) both have a wider range and are found in the entire area. The ranges of $I$. calligraphus and I. pini never overlap, while I. avulsus and I. grandicollis are sympatric with both I. calligraphus and I. pini. All four species utilize several species of pine (Pinus) as their host trees, but there is a slight difference in host preferences. Eastern white pine (P. strobus L.) is the major host tree for I. pini in the Southeastern USA, while the other three Ips species below the mountain range use several species of pine, such as loblolly pine (P. taeda L.), shortleaf pine ( $P$. echinata Miller), slash pine ( $P$. elliotii Engelmann), longleaf pine (P. palustris Miller), and Virginia pine (P. virginiana Muller).

Bark beetles, like many insects, utilize semiochemicals to find a mate and to concentrate their attacks on suitable host plants [5-7]. As a widespread genus, Ips spp. beetles were among the first to be investigated for their pheromones [8]. Vité et al. [9] found that many Ips species produced ipsenol, ipsdienol, or cis-verbenol as their aggregation pheromones either alone or in combination. At this time, a single compound was often regarded as the entire pheromone of a species $[10,11]$. Subsequently, the pheromones of several bark beetle species have been reinvestigated, and new compounds have been identified and shown to be synergistic pheromone components of the aggregation pheromone blends [12-14], increasing trap catches up to more than 25 times. All these reinvestigations clearly showed that bark beetle aggregation pheromones very rarely are found to be 
a single component; instead most are based on two or more beetle-produced compounds.

The male-produced pheromone compounds that were initially identified in the four Ips species in the southeastern USA were ipsdienol in I. avulsus, I. calligraphus, and I. pini; ipsenol in I. grandicollis; and cis-verbenol in I. calligraphus [9]. Based on range overlap in these species, the three identified compounds will not provide sufficient adequate species isolation on a pheromone basis. The aim of our study was to reinvestigate for the presence of new, male-produced pheromone candidates for all the four species and test them in subtractive trap bioassays in the field. In addition, we tested interspecific attraction and inhibition, the latter being common among sympatric bark beetle species.

\section{Materials and Methods}

2.1. Biological Material. Beetles were collected as brood in host pine logs and brought in to the laboratory. Ips avulsus, I. calligraphus, and I. grandicollis were all collected in forests around Athens, Georgia, while beetles of I. pini were collected in the Nanthahala National Forest, North Carolina. The emerging broods were then allowed to attack fresh pine bolts in the laboratory and kept at ambient temperature and humidity. Georgia beetles were established on loblolly pine, while I. pini was reared on Eastern white pine. The logs were predrilled with holes $(\varnothing 2.5 \mathrm{~mm})$ to spread the attacks over the log surface. The attacking I. avulsus, I. calligraphus, and I. grandicollis beetles were cut out of the bark after 36 hours, and single males in nuptial chambers were stored on dry ice until dissection and chemical analysis.

The I. pini beetles were collected during August and needed a diapause to produce pheromones. Without this diapause, the male beetles did not produce any pheromone components. In order to mimic a natural diapause, the beetles were allowed to attack a cut bolt of Eastern white pine, and the wood was put in a cold storage $\left(5^{\circ} \mathrm{C}, 80 \% \mathrm{RH}\right)$ for three weeks. The beetles were then removed from the bolt and reintroduced on new bolts of Eastern white pine. The reattacking beetles were cut out of their host tree after 48 and 96 hours and kept on dry ice until dissection and chemical analysis.

In order to estimate the pheromone release rates during the second day after the initiation of the attack, beetle attacks were also individually induced to provide sites for aerations. These males were put in predrilled holes in the bark $(\varnothing$ $2.5 \mathrm{~mm}$ ) and covered with gelatin capsules (No. 000; Eli Lilly \& Co., Indianapolis, IN, USA) that fit into a groove made by a cork borer $(\varnothing 9.5 \mathrm{~mm})$ centered over an attack hole. The gelatin capsule prevented the males from escaping during the initiation of the attack. During the aeration, the gelatin capsule was removed and a cut piece of a Pasteur pipette was fitted over the entrance hole and was held firmly to the bark with a rubber band. A Teflon tube $(55 \mathrm{~mm} \times \varnothing 3 \mathrm{~mm})$ filled with Porapak Q (65 mg, mesh 60-80; Supelco, Bellefonte, PA, USA) fitted in the constraints of the Pasteur pipette, modified from Birgersson and Bergström [15]. Airflow of $50 \mathrm{~mL} / \mathrm{min}$ was achieved with battery-operated pumps (Gilian HFS
513A; Gilian Instrument Corp., West Caldwell, NJ, USA), and collections continued for 3 hours. Similar aerations were also collected in the field from individual attacks, to compare the release rates of pheromone in the laboratory with those in the field. Aeration columns were kept in Nalgene cryogenic vials (Nalge Nunc Internat., Rochester, NY, USA) on dry ice or in a $-83^{\circ} \mathrm{C}$ freezer until extraction and chemical analysis.

2.2. Chemical Analysis. Beetles kept on dry ice were allowed to thaw and immediately the hindgut was dissected, using a pair of sharp forceps, and transferred to a $0.3 \mathrm{~mL}$ ReactiVial (Pierce Chem. Comp., Rockford, IL, USA) chilled on dry ice, according to Birgersson et al. [16]. The sex of each beetle was absolutely determined at dissection, by the presence of aedeagus or spermatheca. Extracts were made in batches of 8 to 20 male beetles in $10 \mu \mathrm{L}$ of redistilled pentane with $10 \mathrm{ng} / \mu \mathrm{L}$ of heptyl acetate $\left(\mathrm{C}_{7} \mathrm{Ac}\right)$ for extracts of I. avulsus and I. grandicollis, and $100 \mathrm{ng} / \mu \mathrm{L}$ of $\mathrm{C}_{7} \mathrm{Ac}$ for extracts of I. calligraphus and I. pini, giving $100 \mathrm{ng}$ and $1000 \mathrm{ng}$ of $\mathrm{C}_{7} \mathrm{Ac}$, respectively, as a quantification standard. The hindgut extracts were concentrated to less than $5 \mu \mathrm{L}$ before the chemical analysis.

2.3. Aerations. The aeration columns were allowed to equilibrate at room temperature and were then eluted with $500 \mu \mathrm{L}$ diethyl ether into tapered vial inserts (Agilent Technologies), and $1000 \mathrm{ng}$ of $\mathrm{C}_{7} \mathrm{Ac}$ was added to each extract as a quantification standard. The extracts were allowed to concentrate in a fume hood to the volume of around $20 \mu \mathrm{L}$ prior to chemical analysis.

2.4. Chemical Identification and Quantification. All chemical analyses were performed on a combined gas chromatograph and mass spectrometer (GC-MS): Hewlett-Packard (HP) 5890 GC and a HP 5970 MS (nowadays Agilent Technologies, Palo Alto, CA, USA). The GC was equipped with either a $30 \mathrm{~m} \times 0.25 \mathrm{~mm}$ fused silica column coated with HP-1 ( $100 \%$ methyl siloxane, $\mathrm{df}=0.5 \mu \mathrm{m}$ : Agilent Technologies) or a $50 \mathrm{~m} \times 0.25 \mathrm{~mm}$ fused silica column, coated with HPFFAP (nitroterphthalic acid modified polyethylene glycol, df $=0.5 \mu \mathrm{m}$; Agilent Technologies). Temperature programming was $50^{\circ} \mathrm{C}$ for 5 minutes, $8^{\circ} \mathrm{C} / \mathrm{min}$ to $225^{\circ} \mathrm{C}$, followed by isothermal at $225^{\circ} \mathrm{C}$ for 10 minutes for both columns. Injector temperature was $200^{\circ} \mathrm{C}$ and the transfer line was kept at $225^{\circ} \mathrm{C}$. Helium was used as mobile phase, at $35 \mathrm{~cm} / \mathrm{s}$, and the electron impact (EI mode) mass spectra were obtained at $70 \mathrm{eV}$. All samples, $2 \mu \mathrm{L}$ each, were injected manually and splitless for 0.5 minutes. Compounds were identified by their GC retentions times and obtained mass spectra and compared with authentic samples of synthetic references. Mass spectra were also compared to both commercially available MS libraries (NBS and NIST) and to our own MS database.

For chemical analyses two different fused silica columns were used, each with stationary phases of different polarity, to avoid the possible coelution of unknown compounds rendering detection, and identification difficult. Compounds that might coelute on a nonpolar stationary phase, such 
TABLE 1: Compounds used in field bioassays: abbreviation, purity, and source.

\begin{tabular}{lccl}
\hline Compound & Abbreviation & Purity & Purchased from \\
\hline 2-methyl-3-buten-2-ol & MB & $98 \%$ & Aldrich Chemical Company Inc., \\
$( \pm)$-ipsdienol & Id & $99 \%$ & Milwaukee, WI, USA \\
$( \pm)$-ipsenol & Ie & $99 \%$ & PheroTech Inc., Delta, BC, Canada \\
E-myrcenol & EM & $99 \%$ & PheroTech Inc., Delta, BC, Canada \\
Geraniol & Ger & $99 \%$ & Dr. W. Francke, Universität Hamburg, \\
Lanierone & Ln & $98 \%$ & Hamburg, Germany \\
$(-)-(4 S)$-cis-verbenol & $\mathrm{cV}$ & $99 \%$ & Aldrich Inc., Milwaukee, WI, USA \\
& & & University, Sundsvall, Sweden \\
& & & Aldrich, Milwaukee, WI, USA \\
\hline
\end{tabular}

as HP-1, most often will separate on a medium polar to polar stationary phase, like HP-FFAP, and vice versa. The dual analyses did not show any new compounds on either column. During the manual analysis of the obtained GC-MS chromatograms (HP Standalone data analysis workstation), every single peak in every analysis was checked, in order to identify and confirm the identity of new compounds. In addition, the extracted ion current profiles (EICPs) [17] allowed us to search for compounds identified in the analyses of one species, in the analytical run of another species. The use of EICP also lowered the limit of detection for the compounds to far below $1 \mathrm{ng}$ injected on the GC-MS, and even less per analyzed beetle. This thorough search for new compounds probably allowed us to identify all ecologically relevant compounds in the hindgut extracts. Compounds present in one single analysis, and never found in other analyses, were defined as contaminants, since several analyses were made on each species on each column. Control analyses of extracting solvents also helped us to rule out contaminants.

Quantification of the identified compounds in the analyses was based on standard curves of selected oxygenated monoterpenes. The standard curve covered four orders of magnitude, from $1 \mathrm{ng}$ to $10 \mu \mathrm{g}$. For identified compounds, not included in the standard curve, their response factors were assumed to be similar to related compounds in the standard mixture. In aeration analyses, with hundreds of compounds from the host trees, the quantifications were based on prominent MS fragments in the selected male beetle-produced compounds and in the quantification standard, according to Garland and Powell [17] and Dobson [18]. This method gives extracted ion current profiles (EICPs), which increases the signal-to-noise ratio tenfolds, depending on which MS fragment extracted. The EICPmethod also allowed us to search for compounds identified from one analysis, in all the other analyses. As controls, both the hindgut extract solvent and the aeration extracting solvent were analyzed for contaminants.

Chiral analyses of ipsdienol, ipsenol, and cis-verbenol were made without derivatization of pooled remains of hindgut extract on an HP 5890A GC-FID equipped with a fused silica column $(30 \mathrm{~m} \times 0.25 \mathrm{~mm})$ coated with methylated $\beta$-cyclodextrin ( $\mathrm{df}=0.25 \mu \mathrm{m}$; cylodex-B J\&W Scientific
Inc., Folsom, CA, USA), according to König et al. [19]. Injector and detector temperatures were $175^{\circ} \mathrm{C}$ and $225^{\circ} \mathrm{C}$, respectively, and column temperature was held constant at $125^{\circ} \mathrm{C}$, with $\mathrm{N}_{2}$ as carrier gas at $15 \mathrm{~cm} / \mathrm{s}$. All samples were injected manually, $2 \mu \mathrm{L}$ each, and injected splitless for 0.1 minutes.

2.5. Field Bioassays. Multiple subtractive field bioassays [20] were carried out, and the compounds used in these bioassays were selected based on the hindgut analyses made on the attacking males of each species. Compounds identified in sympatric species were added as tentative inhibitors. Release rates of the selected compounds were based on the individual entrance hole aeration analyses, made both from laboratory introduced and naturally attacking bark beetles. The release rates of the baits corresponded to the estimated amounts similar to 500-1000 male attacks on a host tree. All compounds used in the bioassays are listed in Table 1.

The compounds of each bait were mixed and dissolved in nonane and released at the listed hourly rate through $5 \mathrm{~cm} \times$ $1.5 \mathrm{~mm}$ Teflon tubing, lined with a cotton yarn wick, inserted through a hole drilled in the screw top of a $2 \mathrm{~mL}$ glass vial [21]. These "wick-baits" were attached to the middle of 12 unit Lindgren multifunnel traps (Phero Tech Inc., Delta, BC, Canada) with binder-clips. The traps within each set were separated by at least 8 meters, twice the distance between attacked and nonattacked trees in the area. Several sets of traps, separated by at least 50 meters, were used in each bioassay. The trapsets were installed on recent clear-cuts within the range of each bark beetle species. The traps were emptied and randomized regularly, either several times a day when any trapping bait had $\geq 50$ beetles, or on a weekly basis, depending on the population density.

The first bioassays, made in July 1990, comprised four "species-specific" pheromone blends and a subtractive assay of six volatiles identified in male hindgut extracts (Table 2). Traps were set up in Francis Marion National Forest, South Carolina, to trap I. avulsus, I. calligraphus, and I. grandicollis, and in Nantahala National Forest, North Carolina, to trap I. pini. The results from the subtractive part of this assay clearly showed very strong interspecific inhibition, and that further 
Table 2: Pilot study, Francis Marion National Forest, SC, and Nantahala National Forest, NC, July 1990: pheromone candidates released from Wick-baits: for abbreviations, see Table 1. Release rates are given in $\mu \mathrm{g} / \mathrm{h}$.

\begin{tabular}{lcccccc}
\hline & MB & Id & Ie & EM & Ger & cV \\
\hline avulsus-bait & 20 & 20 & - & - & - & 2.5 \\
calligraphus-bait & - & 100 & - & - & 5.0 & 50 \\
grandicollis-bait & - & 1.0 & 50 & 5.0 & 2.5 & 2.5 \\
pini-bait & - & 250 & - & 20 & 10 & 20 \\
Subtractive assay & & & & & & \\
$\quad$ Total blend & 20 & 250 & 50 & 20 & 10 & 50 \\
$\quad$ (TB) & - & 250 & 50 & 20 & 10 & 50 \\
$\quad$ TB-MB & 20 & - & 50 & 20 & 10 & 50 \\
$\quad$ TB-Id & 20 & 250 & - & 20 & 10 & 50 \\
$\quad$ TB-Ie & 20 & 250 & 50 & - & 10 & 50 \\
$\quad$ TB-EM & 20 & 250 & 50 & 20 & - & 50 \\
$\quad$ TB-Ger & 20 & 250 & 50 & 20 & 10 & - \\
$\quad$ TB-cV & - & - & - & - & - & - \\
Blank & & & & & &
\end{tabular}

bioassays had to be based on species-specific subtractive assays, with addition of possible interspecific inhibitors.

The total set of the I. grandicollis subtractive and additive assay (Table 3) was performed in Oconee National Forest, GA, April 1992. The full blend for I. avulsus (Table 3) was bioassayed at Fort Benning, AL, September 1991, in conjunction with the bioassay of I. calligraphus (Table 3 ), but at different sites. The bioassay for I. pini (Table 3) was conducted in Rabun Co, GA, June and July 1992, and was checked and randomized on a weekly basis.

2.6. Statistical Design. Completely randomized, Latin square designs were used to position the traps in each field bioassay. Male and female beetle responses were analyzed separately, with the exception of I. avulsus trapped on I. pini bait (too many beetles trapped for sexing). Trap catches, as percentage catch to each bait in each replicate, were analyzed by ANOVA as square root $(X+0.5)$ and arcsin square root $(\% X)$ transformations. Treatment means were separated using the Fisher's protected LSD option at $\alpha=0.01$ when the entry $F$-statistic was significant at the 0.05 level. All analyses were performed using SAS-PC (SAS-Institute, Carey, NC).

\section{Results}

3.1. Chemical Analyses. In total, 15 bark beetle-produced, oxygenated compounds were identified and quantified in hindgut extracts from unmated males of the four Ips species investigated (Table 4, Figure 1). All the species had either ipsdienol or ipsenol and cis-verbenol, which are the most common pheromone components in the genus [9]. E-myrcenol was identified in I. grandicollis and I. pini male hindguts. In addition, geraniol was identified in all species. Lanierone was identified in I. pini and I. avulsus, and 2methyl-3-buten-2-ol was identified in I. avulsus. Several oxygenated monoterpenes, regarded as detoxification products of host tree monoterpene hydrocarbons, were identified in all species, especially in I. calligraphus and I. pini. 2-Phenyl ethanol was identified in all species.

The males of $I$. pini were in preparation for their overwintering diapause, when they were collected in August, and produced only trace amounts of oxygenated monoterpenes when put on new logs, of their host tree, Eastern white pine (Figure 2(a)). After the cold stratification, they still did not produce any pheromone components when placed on new logs, but their production of host related oxygenated monoterpenes had increased substantially (Figure 2(b)). This cohort of beetles, when excised and put on new logs did not produce any pheromone for the first days. After 48 hours in new logs they still only contained the oxygenated monoterpenes, related to host tree resin (Figure 2(c), Table 4). However, after 96 hours following cold treatment, they produced the pheromone components ipsdienol and lanierone in large amounts. At this time only trace amounts of host tree-related, oxygenated monoterpenes were detected (Figure 2(d), Table 4).

Chiral analyses were made on ipsdienol, ipsenol, and cisverbenol. All species produced (-)-(S)-cis-verbenol. Ipsenol in I. grandicollis was enantiomerically pure, with $100 \%$ $(-)-(S)$-isomer, while the enantiomeric compositions of ipsdienol varied widely among the three species (Table 5 ). The aerations of male beetles in nuptial chambers showed that the average hourly release of pheromone components closely approximates the average hindgut amounts (Table 4). Based on these results, the field bioassays were set up to release the amount of each compound equal to 500-1000 male attacks.

3.2. Field Bioassays. The results from the pilot bioassay clearly showed that there were too much interspecific inhibitions to do subtractive bioassays of all the identified compounds in one assay. This pilot study was followed by species-specific subtractive bioassays, with compounds identified in sympatric species added as tentative inhibitors.

When ipsenol was subtracted in the I. grandicollis subtractive assay, the trap catches was reduced to that of the blank, clearly indicating ipsenol as the key pheromone component in this species (Figure 3(a)). When cis-verbenol was omitted, the trap catches of both males and females dropped significantly, but not as much as when ipsenol was excluded. The trap catch of females was significantly lower when $E$-myrcenol was subtracted from the total blend, while the males were not significantly affected. Geraniol does not seem to affect the attraction of either sex. The addition of ipsdienol showed an inhibition to I. grandicollis. Lanierone added alone also has a significant negative impact on the trap catches. When both ipsdienol and lanierone were added in combination to the full I. grandicollis blend, trap catches were significantly lower, and especially so for males, where the number of beetles trapped was as low as the blank. 
TABle 3: Subtractive bioassay: pheromone candidates released from Wick-baits:- for abbreviations, see Table 1. Release rates are given in $\mu \mathrm{g} / \mathrm{h}$.

\begin{tabular}{|c|c|c|c|c|c|c|}
\hline \multicolumn{7}{|c|}{ Ips grandicollis bait, used in Oconee National Forest, GA, April 1992.} \\
\hline & Ie & EM & Ger & $\mathrm{cV}$ & Id & Ln \\
\hline Total blend & 250 & 65 & 65 & 250 & - & - \\
\hline$-"--\mathrm{Ie}$ & - & 65 & 65 & 250 & - & - \\
\hline$-"--\mathrm{EM}$ & 250 & - & 65 & 250 & - & - \\
\hline$-"--$ Ger & 250 & 65 & - & 250 & - & - \\
\hline$-"--c V$ & 250 & 65 & 65 & - & - & - \\
\hline$-"-+$ Id & 250 & 65 & 65 & 250 & 500 & - \\
\hline$-"-+\operatorname{Ln}$ & 250 & 65 & 65 & 250 & - & 65 \\
\hline$-"-+\mathrm{Id}+\mathrm{Ln}$ & 250 & 65 & 65 & 250 & 500 & 65 \\
\hline Blank & - & - & - & - & - & 一 \\
\hline \multicolumn{7}{|c|}{ Ips avulsus bait, used at Fort Benning, AL, September, 1991.} \\
\hline & $\mathrm{MB}$ & Id & Ln & $\mathrm{cV}$ & $\mathrm{Ie}$ & EM \\
\hline Total blend & 500 & 500 & 65 & 250 & - & - \\
\hline$-"--\mathrm{MB}$ & - & 500 & 65 & 250 & - & - \\
\hline - " - - Id & 500 & - & 65 & 250 & - & - \\
\hline$-"--\operatorname{Ln}$ & 500 & 500 & - & 250 & - & - \\
\hline$-"--c V$ & 500 & 500 & 65 & - & - & 一 \\
\hline$-"-+\mathrm{Ie}$ & 500 & 500 & 65 & 250 & 250 & - \\
\hline$-"-+\mathrm{EM}$ & 500 & 500 & 65 & 250 & - & 65 \\
\hline$-"-+\mathrm{Ie}+\mathrm{EM}$ & 500 & 500 & 65 & 250 & 250 & 65 \\
\hline Blank & - & - & - & - & - & - \\
\hline \multicolumn{7}{|c|}{ Ips calligraphus bait, used at Fort Benning, AL, September 1991.} \\
\hline & Id & Ger & $\mathrm{cV}$ & Ie & EM & Ln \\
\hline Total blend & 500 & 65 & 250 & - & - & - \\
\hline - " - - Id & - & 65 & 250 & - & - & - \\
\hline$-"--$ Ger & 500 & - & 250 & - & - & - \\
\hline$-"--c V$ & 500 & 65 & - & - & - & - \\
\hline$-"-+\mathrm{Ie}$ & 500 & 65 & 250 & 250 & - & - \\
\hline$-"-+\mathrm{EM}$ & 500 & 65 & 250 & - & 65 & - \\
\hline$-"-+\operatorname{Ln}$ & 500 & 65 & 250 & - & - & 65 \\
\hline$-"-+\mathrm{Ie}+\mathrm{EM}+\mathrm{Ln}$ & 500 & 65 & 250 & 250 & 65 & 65 \\
\hline Blank & - & - & - & - & - & - \\
\hline \multicolumn{7}{|c|}{ Ips pini bait, used in Rabun county, GA, June and July 1992.} \\
\hline & Id & EM & Ger & Ln & $\mathrm{cV}$ & Ie \\
\hline Total blend & 500 & 65 & 65 & 65 & 250 & - \\
\hline -" - - Id & - & 65 & 65 & 65 & 250 & - \\
\hline$-"--\mathrm{EM}$ & 500 & - & 65 & 65 & 250 & - \\
\hline$-"--$ Ger & 500 & 65 & - & 65 & 250 & - \\
\hline$-"--\operatorname{Ln}$ & 500 & 65 & 65 & - & 250 & - \\
\hline$-"--c V$ & 500 & 65 & 65 & 65 & - & - \\
\hline$-"-+\mathrm{Ie}$ & 500 & 65 & 65 & 65 & 250 & 250 \\
\hline Blank & - & - & - & - & - & \\
\hline
\end{tabular}

There was no attraction by I. avulsus to the I. grandicollis blend. When ipsdienol was added, there was a weak attraction, while addition of lanierone alone showed no attraction to I. avulsus. However, when both ipsdienol and lanierone were added to the full I. grandicollis blend, the trap catches of
I. avulsus peaked (Figure 3(b)). The number of I. calligraphus trapped in the bioassay with I. grandicollis baits was too low for statistical analysis, even though most I. calligraphus were trapped when ipsdienol was added alone to the I. grandicollis blend. 


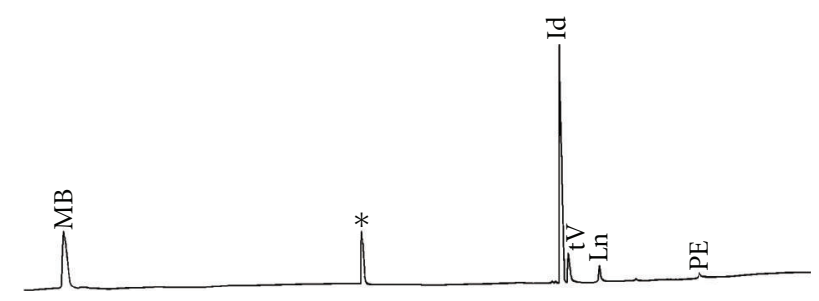

(a)

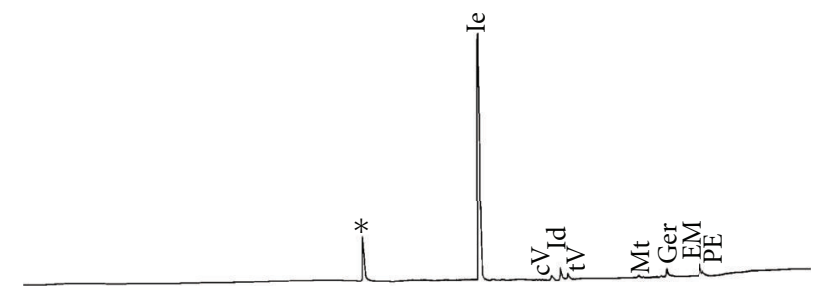

(c)

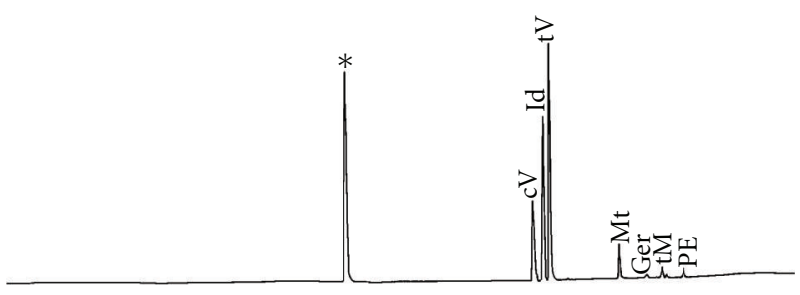

(b)

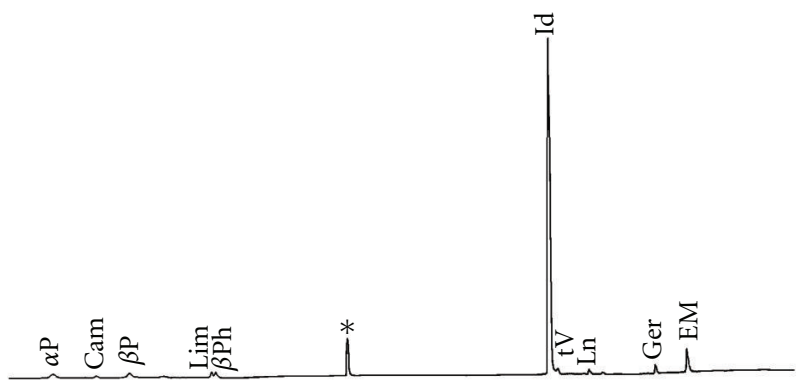

(d)

Figure 1: GC chromatograms from GC-MS analyses of male hindgut extracts. MB: 2-methyl-3-buten-2-ol; Id: ipsdienol; Ie: ipsenol; cV: cis-verbenol; tV: trans-verbenol; Ln: lanierone; Mt: myrtenol; Ger: geraniol; tM: trans-myrtanol; EM: E-myrcenol; PE: 2-phenyl ethanol; *: internal quantification standard, heptyl acetate $\left(\mathrm{C}_{7} \mathrm{Ac}\right)$ amount varies between sample - see the following (for full list of identified compounds and quantities, see Table 4). (a) I. avulsus 15 males: $\mathrm{C}_{7} \mathrm{Ac}$ is $100 \mathrm{ng}$. (b) I. calligraphus 4 males: $\mathrm{C}_{7} \mathrm{Ac}$ is $1000 \mathrm{ng}$. (c) I. grandicollis 5 males: $C_{7}$ Ac is $100 \mathrm{ng}$. (d) I. pini 10 males: $C_{7}$ Ac is $1000 \mathrm{ng}$.

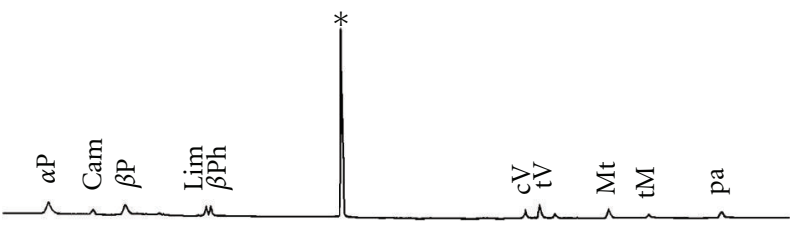

(a)

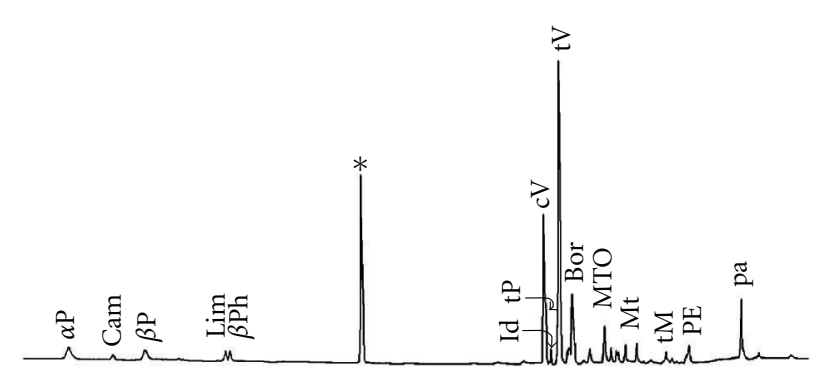

(c)

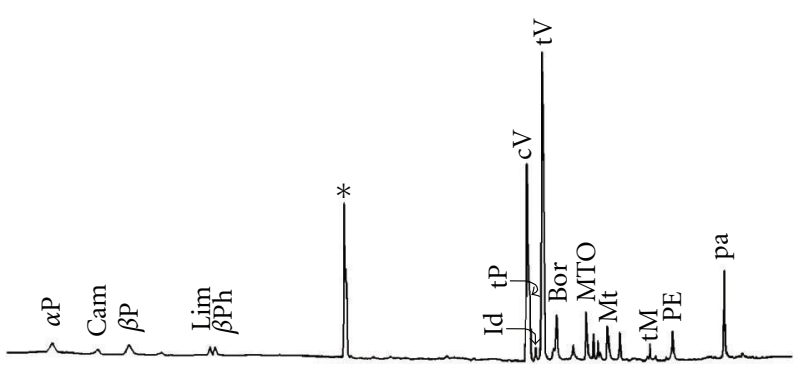

(b)

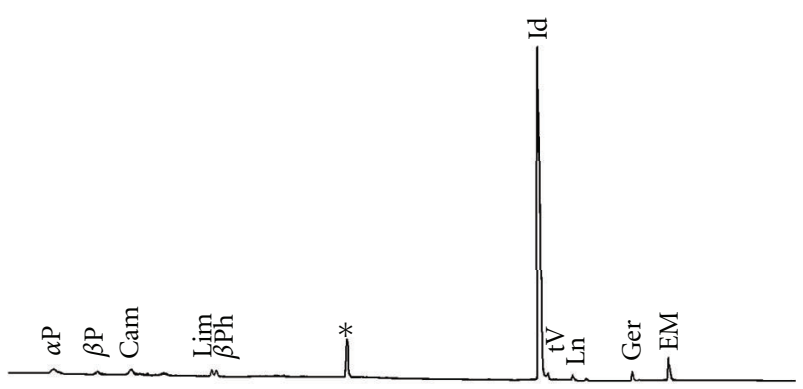

(d)

FIGURE 2: GC chromatograms from GC-MS analyses of I. pini male hindgut extracts at different overwintering/diapause status. $\alpha$ P: $\alpha$-pinene; Cam: camphene; $\beta \mathrm{P}: \beta$-pinene; Lim: limonene; $\beta \mathrm{Ph}: \beta$-phellandrene; Id: ipsdienol; cv: cis-verbenol; tP: trans-pinocarveol; tV: trans-verbenol; Bor: borneol; MTO: oxygenated monoterpenes; Mt: myrtenol; Ger: geraniol; tM: trans-myrtanol; EM: E-myrcenol; Pa: perilla alcohol; Ln: lanierone; PE: 2-phenyl ethanol $*$ : internal quantification standard, heptyl acetate $\left(\mathrm{C}_{7} \mathrm{Ac}\right)$ amount varies between sample-see the following. (a) Late fall; in diapauses, 5 males; $\mathrm{C}_{7} \mathrm{Ac}$ is $100 \mathrm{ng}$. (b) Overwintering, cut out of bolts; 8 males; $\mathrm{C}_{7} \mathrm{Ac}$ is $1000 \mathrm{ng}$. (c) Overwintering, cut out of bolts, on new bolts 48 hrs; 5 males; $\mathrm{C}_{7}$ Ac is $1000 \mathrm{ng}$. (d) Overwintering, cut out of bolts, on new bolts 96 hrs; 10 males; $\mathrm{C}_{7} \mathrm{Ac}$ is $1000 \mathrm{ng}$. 
TABLE 4: Average amounts of volatiles identified in hindgut extracts: ng/unmated male.

\begin{tabular}{|c|c|c|c|c|c|}
\hline \multirow{2}{*}{ Compound } & \multirow{2}{*}{ I.avulses } & \multirow{2}{*}{ I. calligraphus } & \multirow{2}{*}{ I. grandicollis } & \multicolumn{2}{|c|}{ I. pini } \\
\hline & & & & $48 \mathrm{~h}$ & $96 \mathrm{~h}$ \\
\hline 232-metylbutenol & 20 & - & - & - & - \\
\hline Ipsenol & - & - & 120 & - & - \\
\hline ipsdienol & 20 & 275 & $\sim 0.5$ & 8.1 & 725 \\
\hline E-myrcenol & - & - & 6.0 & 5.6 & 61 \\
\hline geraniol & $(+)$ & 6.5 & 3.0 & - & 20 \\
\hline lanierone & 2.0 & - & - & 7.4 & 23 \\
\hline cis-verbenol & 2.5 & 135 & $\sim 0.5$ & 87 & 6.0 \\
\hline trans-verbenol & 7.5 & 400 & $\sim 1.0$ & 170 & 10 \\
\hline myrtenol & 1.0 & 90 & $\sim 0.5$ & 11 & - \\
\hline trans-pinocarveol & - & 11 & - & 27 & - \\
\hline trans-myrtanol & - & 30 & - & 4.5 & - \\
\hline cis-myrtanol & - & 2.0 & - & 2.5 & - \\
\hline perilla alcohol & - & - & - & 34 & - \\
\hline 2-phenylethanol & 1.0 & 15 & 3.0 & 11 & - \\
\hline borneol & - & - & - & 47 & - \\
\hline
\end{tabular}

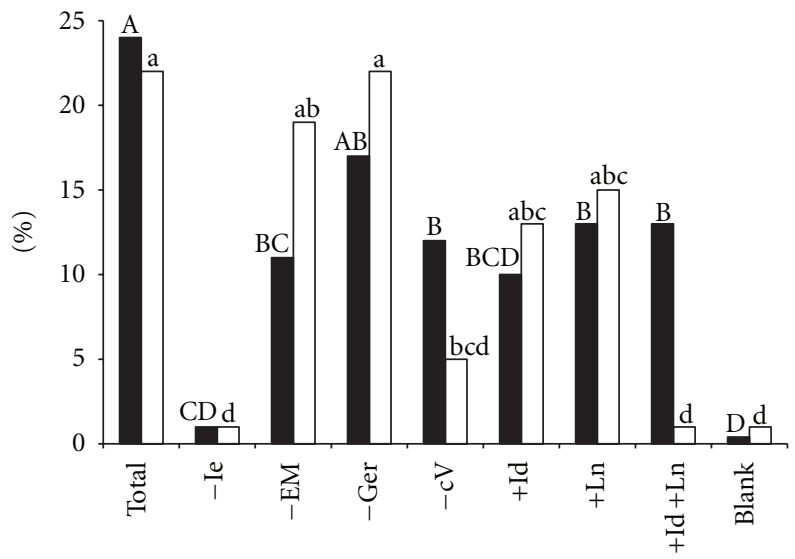

(a)

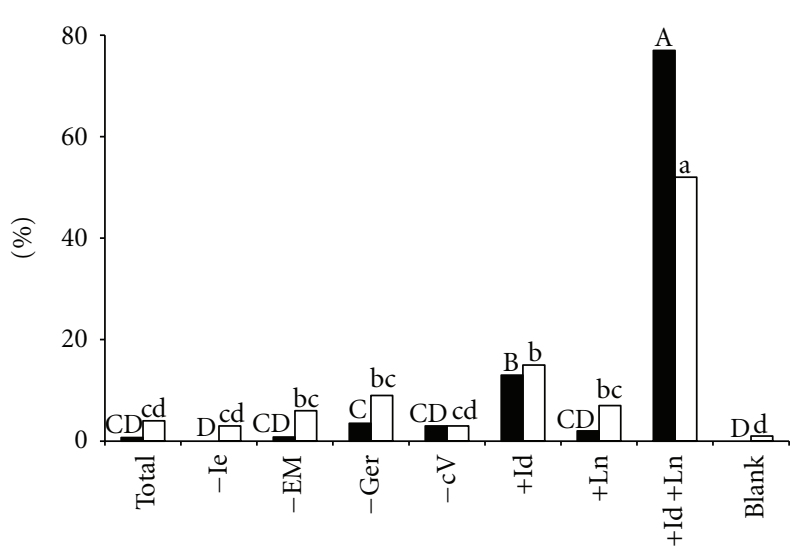

(b)

FIGURE 3: Percentage trap catches in a subtractive and additive field bioassay of I. grandicollis-bait: (a) I. grandicollis and (b) I. avulses, (for bait information, see Table 3). $\mathbf{\text { females; }} \square$ males. Bars with same letter are not significantly different. $n=6$; total trap catches: I. grandicollis 363 우, $2350^{7} 0^{7}$; I. avulsus 341 우, $2290^{7} \sigma^{x}$.

TABLE 5: Chiral analysis of ipsdienol in three species of Ips.

\begin{tabular}{lcc}
\hline & \multicolumn{2}{c}{ Ipsdienol } \\
\hline I. avulsus & $(+)-(S)$ & $(-)-(R)$ \\
I. pini & $85.4 \%$ & $14.6 \%$ \\
I. calligraphus & $61.4 \%$ & $38.6 \%$ \\
\hline
\end{tabular}

The chemical analysis of hindgut volatiles in unmated males of $I$. avulsus revealed two new pheromone component candidates, 2-methyl-3-buten-2-ol and lanierone. Both of these compounds were included in the field subtractive bioassay, together with ipsdienol and cis-verbenol, also identified in the hindgut extracts (Table 4). The results clearly show that ipsdienol is the key pheromone component in this species, as the number of trapped beetles was as low as the blank when this compound was omitted (Figure 4(a)). Lanierone did prove to be a pheromone component of this species, since the trap catch of both sexes were significantly lower without this compound, compared to the full blend. When methylbutenol was excluded, the trap catches were reduced somewhat, but not significantly different from the full blend. The exclusion of cis-verbenol had no effect on the trap catch, which suggests that, in I. avulsus, this compound is only a detoxification product of the host resin monoterpene $(-)-(S)$ - $\alpha$-pinene, which is unusual for beetles in the genus Ips $[5,6]$. None of the added compounds, ipsenol and/or E-myrcenol, hypothesized to be inhibitory 


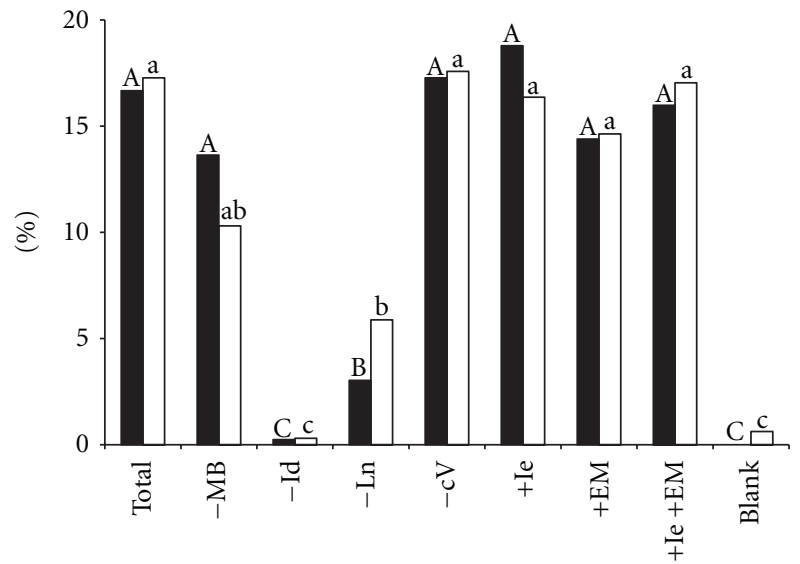

(a)

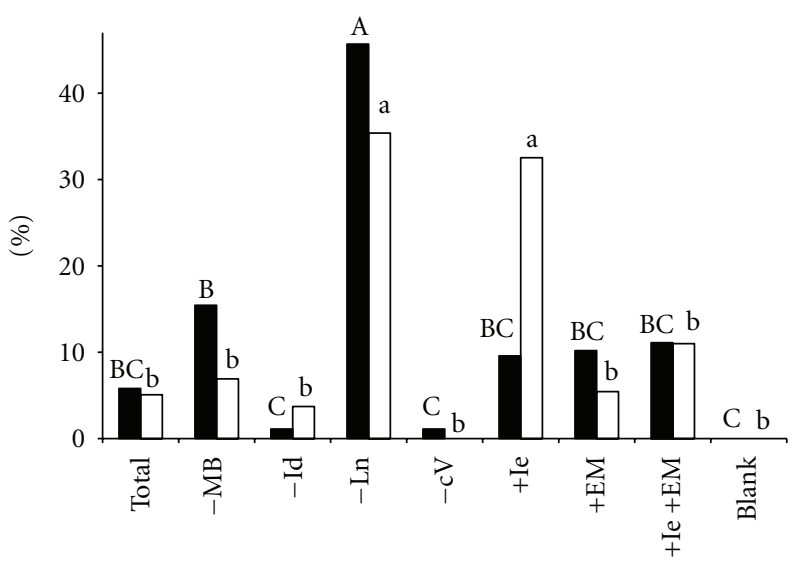

(b)

FIgURE 4: Percentage trap catches in a subtractive and additive field bioassay of I. avulsus-bait: (a) I. avulsus and (b) I. calligraphus. (for bait information, see Table 3). $\square$ females; $\square$ males. Bars with same letter are not significantly different. $n=7$; total trap catches: I. avulsus 1673 우, 795 o $^{\top}$; I. calligraphus 209 우, 135 ○ $^{\top}$.

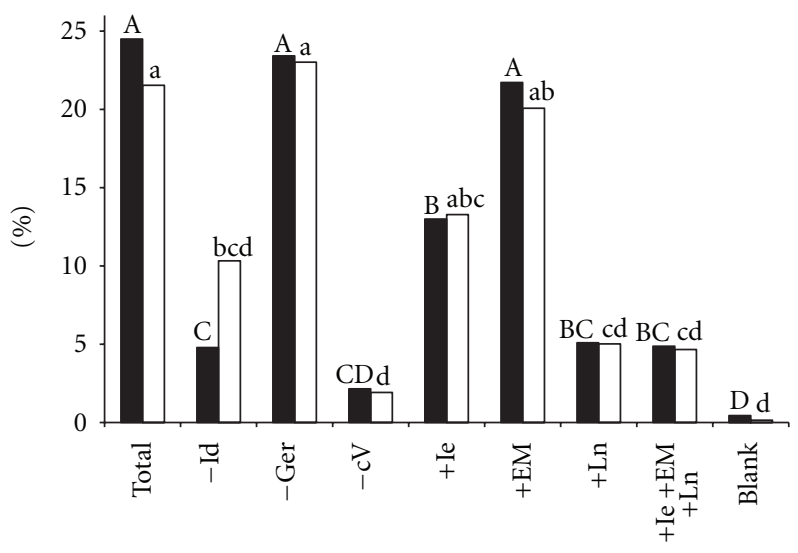

(a)

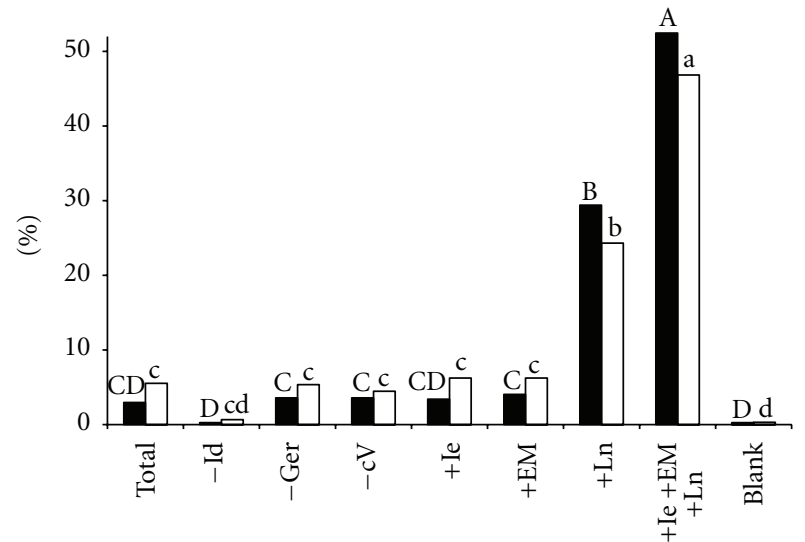

(b)

FIgure 5: Percentage trap catches in a subtractive and additive field bioassay of I. calligraphus-bait: (a) I. calligraphus, and (b) I. avulsus. (for bait information, see Table 3). $\square$ females; $\square$ males. Bars with same letter are not significantly different. $n=6$; total trap catches: $I$. calligraphus 523 우, $3780^{7} \sigma^{7}$; I. avulsus 225 우, $1830^{7} \sigma^{\top}$.

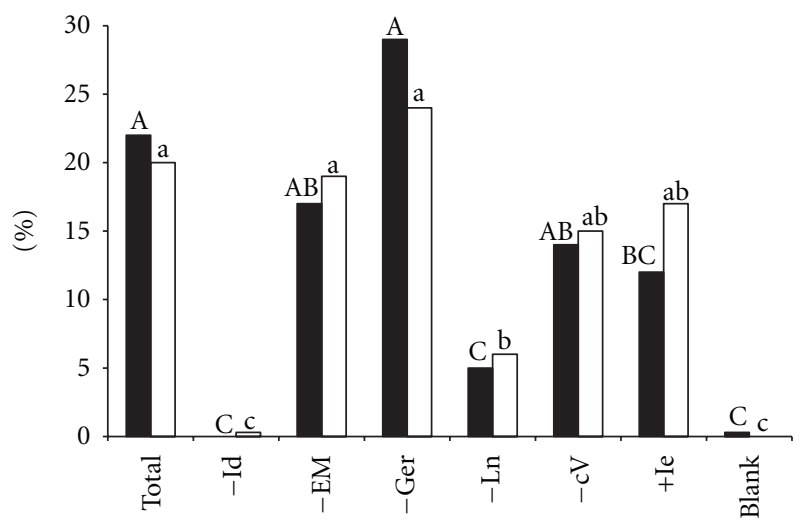

(a)

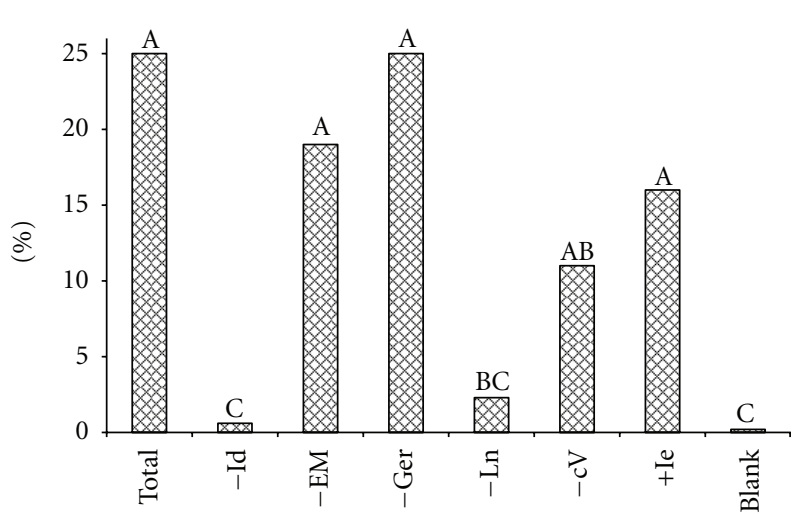

(b)

FIGURE 6: Percentage trap-catches in a subtractive and additive field bioassay of $I$. pini-bait: (a) I. pini (b) I. avulsus. (for bait information, see Table 3). $\square$ females; $\square$ males. Bars with same letter are not significantly different. $n=5$; total trap catches: I.pini 602 oㅇ, $296 \sigma^{7} \sigma^{7}$; I. avulsus 7,000 우우 $+0^{7} \sigma^{7}$. 
to this species, had any effect on the trap catches on either sex. Most I. calligraphus were trapped when lanierone was omitted from the total blend of the I. avulsus bait. This indicates that lanierone is an inhibitor to I. calligraphus (Figure 4(b)). No other compound in the I. avulsus bait had any significant effect on I. calligraphus, even though exclusion of methylbutenol gave a higher percentage trap catch than the total bait, however not significantly. Surprisingly, when ipsenol was added to the bait, the number of trapped I. calligraphus males increased significantly, compared to the total blend.

The major pheromone candidates in I. calligraphus from the hindgut analyses were ipsdienol and cis-verbenol. Both these compounds together with geraniol were tested in the subtractive field bioassay, with ipsenol, E-myrcenol, and lanierone as possible interspecific inhibitors (Table 3). Both of the suggested pheromone components proved to be necessary for the pheromone blend of this species, while geraniol had no effect on the trap catches (Figure 5(a)). In this species, cis-verbenol seems to be the key pheromone component, with very low trap catches for both sexes, which were not significantly different from the blank, when omitted. Exclusion of ipsdienol significantly reduced the trap catches for both sexes, more for females than for males, but not as much as the exclusion of cis-verbenol. The addition of E-myrcenol did not affect the trap catches, while both ipsenol and lanierone reduced the number of beetles trapped, significantly so by lanierone for both sexes and by ipsenol for females. When all the inhibitory candidates were added, the result was the same as when lanierone was added alone. Ips avulsus shares ipsdienol with I. calligraphus, but very few $I$. avulsus beetles were trapped on the full bait (Figure 5(b)), and logically the trap catches were even lower when ipsdienol was omitted. The number of trapped I. avulsus increased only when lanierone was added to the I. calligraphus bait, and it increased even more when all three putative I. calligraphus inhibitors, lanierone, ipsenol, and E-myrcenol, were added to the full blend.

Ips pini in Georgia is at its southernmost range and is only found at higher elevations. This species also has a diapause, and beetles in the fall are not supposed to be attracted to pheromone. Therefore the subtractive bioassay of this species was undertaken during the early summer. The bait for the subtractive assay was based on the compounds identified in the hindgut extracts, after the beetles had gone through a cold treatment in the laboratory, to mimic a diapause, and were put on new logs for 96 hours (Table 4; Figures 1(d) and 2(d)). Ipsenol was added as a candidate inhibitor. The key pheromone component of this species is ipsdienol, with almost no beetles trapped when this compound was omitted (Figure 6(a)). The exclusion of lanierone from the full blend resulted in low trap catches, significantly less than the full blend, making this compound a pheromone component, synergistically active with ipsdienol. When cis-verbenol was omitted, there was a slight but nonsignificant reduction in the trap catch. The subtraction of either E-myrcenol or geraniol had no effect on the trap catches, when compared to the total blend. The addition of ipsenol significantly lowered trap catch of females, while the reduction in trapped males was not significant. Ips avulsus was also trapped in this assay. However, the number of trapped I. avulsus was too high for sexing the beetles $(\sim 7000)$; therefore only results from combined sexes are presented. The trap catch pattern for $I$. avulsus is very similar to that for I. pini (Figure 6(b)). When ipsdienol is omitted, almost no beetles were trapped, and the subtraction of lanierone also gave significantly lower trap catches, compared to the total blend. Reduced trap catch due to exclusion of cis-verbenol was not significant. Addition of ipsenol did not have any significant effect on the number of beetles trapped.

\section{Discussion}

The chemical analyses revealed new pheromone component candidates in most species. However, these compounds have earlier been identified and found active in other species of Ips. 2-Methyl-3-buten-2-ol in I. avulsus was first identified in I. typographus by Bakke et al. [22], was found to be a synergist to cis-verbenol for that species, and was used in mass trapping programs in Scandinavia and Germany [23-25]. E-Myrcenol in I. grandicollis and I. pini was first identified as a bark beetle pheromone component in $I$. duplicatus [13]. The compound was inactive by itself but increased the trap catches of I. duplicatus 25-fold compared to ipsdienol alone. Teale et al. [14] identified lanierone in $I$. pini, in a rigorous aeration, fractionation, and bioassay study. Lanierone was present in I. avulsus male hindgut extracts, on the average $2 \mathrm{ng}$ per beetle. When the males of I. pini produced their pheromone after cold treatment, there were 10 times more lanierone than found in I. avulsus. Besides the new pheromone components, geraniol was identified in all four species of Ips, but no pheromonal activity could be found. Therefore, this compound must be regarded as a precursor to the de novo produced ipsenol, ipsdienol, and Emyrcenol.

The decision regarding which of the identified compounds to include in the subtractive assay of each species was based on three factors. First, each subtractive bioassay should only include compounds that are produced by the species to test. Second, compounds not included in the specific subtractive assay of one species, but included as a pheromone candidate in another species-specific assay, can be added as an inhibitor candidate and should be added individually and in combination. Third, the basis for exclusion of compounds was those regarded as host tree resin detoxification products, that is, oxygenated monoterpenes. This relationship was partly based on the compounds present in I. pini during the period after cold treatment and the start of their pheromone production (Table 4 and Figures $2(\mathrm{c})$ and 2(d)) and in part on experiences with analyses of Ips species and other bark beetles [21,26]. Large quantities of these monoterpene alcohols reflect the amount of resin the beetles have encountered during their excavation of their nuptial chambers. The only exception in this group is cisverbenol, which has been proven as a pheromone component for several species of Ips $[5,6]$, and was therefore included in the bioassays. The last compound excluded was 2-phenyl 
ethanol, which has been identified in male hindgut extracts of several genera and species of bark beetles. The activity of this compound is still very unclear, as it has been reported to be an attractant synergist [27], or to have no behavioral impact [26], or even reduce the attraction to pheromone components $[28,29]$.

4.1. Subtractive Bioassays of Aggregation Pheromones. For I. grandicollis, the major result is that ipsenol and cis-verbenol are necessary for the pheromone of this species (Figure 3(a)). The subtraction of $E$-myrcenol gave different results in males and females. The subtraction had no significant effect on the trap catches of males but significantly reduced the trap catches of females. Therefore, E-myrcenol might act more as a sex pheromone, rather than an aggregation pheromone component.

Two new compounds were identified in I. avulsus: 2methyl-3-buten-2-ol and lanierone. The subtractive bioassay (Figure 4(a)) clearly shows that the aggregation pheromone is made up of ipsdienol and lanierone. When either of these two compounds was excluded, the trap catches dropped significantly for both sexes. However, when the methylbutenol was subtracted, neither of the sexes showed significantly reduced attraction to the bait, even though overall trap catches were reduced. Therefore, we cannot rule out the possibility that methylbutenol might be a behaviorally active compound. 2-Methyl-3-buten-2-ol in I. typographus has been found to have a close range attractance [30], apparently promoting landing, as hypothesized by Dickens [31], based on electrophysiological studies. The exclusion of cis-verbenol had no effect on the number of beetles trapped, indicating that cis-verbenol is not included in the pheromone of $I$. avulsus (Figure 4).

Males of I. calligraphus produced very few compounds besides the oxygenated monoterpenes related to the host tree resin. The only two compounds that had an effect on the trap catches were ipsdienol and cis-verbenol. Both these compounds are needed for attraction, since subtracting either of them reduces the trap catches dramatically, especially so for cis-verbenol (Figure 5(a)).

Ips pini has a wide range in North America, covering the western and northern states of the USA and the southern parts of the Canadian provinces, and following the Appalachian range into the southeastern USA [2]. This species has been reported to be attracted to different pheromone blends in different regions within its range. For many years, this species was thought to have a one compound pheromone, ipsdienol $[32,33]$. A decade later, $E$ myrcenol was identified [34] and reported to be behaviorally active in British Columbia [35]. Further investigations on the aggregation pheromone in the New York population of this species resulted in the identification of lanierone another year later [14]. The male beetles analyzed in this study produce, besides ipsdienol, both E-myrcenol and lanierone, together with cis-verbenol. The subtractive bioassay clearly showed ipsdienol and lanierone to be critical compounds for the aggregation pheromone of I. pini, in the present Southeastern population. Lanierone alone does not appear to be attractive alone, as the exclusion of ipsdienol reduced catches to the level of the blank. The exclusion of either $E$ myrcenol or cis-verbenol did not have any significant effect on the trap catches, even though somewhat fewer beetles were trapped when cis-verbenol was omitted (Figure 6).

4.2. Interspecific Attraction and Inhibition. The results from the pilot subtractive bioassay showed that interspecific inhibition among the four species of Ips is very strong, as the most beetles were trapped when one of the compounds was omitted from the total subtractive blend. This was the major reason for performing subtractive bioassays for each species and addition of compounds from sympatric species alone and together to test their effects as inhibitors.

The major difference among the species is the presence of ipsdienol or ipsenol. Ips grandicollis is the only species that utilizes ipsenol in its aggregation pheromone, while all the other species produce ipsdienol, as one major aggregation pheromone component. When ipsdienol or lanierone was added individually to the I. grandicollis bait, the trap catches were reduced similar to when cis-verbenol was omitted (Figure 3(a)). When both ipsdienol and lanierone were added together to the total blend, there were significant reductions in trap catches for both sexes of I. grandicollis, and especially so for males. Therefore, male I. grandicollis beetles are less likely to land on a host tree from which ipsdienol and/or lanierone are emitted.

In all species-specific bioassays, sympatric beetles were attracted as well as the target bark beetle species, sometimes to the subtractive part, sometimes to the additive part. As the most abundant species, I. avulsus was always attracted to the same treatment in the bioassays. In the I. grandicollis assay, I. avulsus was only trapped when ipsdienol was added (Figure 3(b)), and especially so in combination with lanierone. This clearly indicates that there is no crossattraction from I. avulsus to the pheromone of I. grandicollis. In addition, I. calligraphus was only attracted in the $I$. grandicollis assay when ipsdienol was added alone.

The three other species of Ips, excluding I. grandicollis, all have ipsdienol in common. Therefore, more of interspecific attraction will be likely. Accordingly, few beetles of I. calligraphus were attracted to the full bait of $I$. avulsus. Only when lanierone was omitted, a significant number of I. calligraphus were attracted to the bait (Figure 4(b)). Furthermore, when lanierone were added to the I. calligraphus blend, there was a significantly reduced number of $I$. calligraphus attracted to the traps (Figure 5(a)). When ipsenol was added to the I. calligraphus bait, the reduction in trapped I. calligraphus was lower, but still significant. On the other hand, when I. avulsus was exposed to the I. calligraphus blend, a low number of beetles were trapped (Figure 5(b)), independent of which compound was subtracted. This indicates that there is no strong attraction to "the total blend", nor is there any inhibitor to $I$. avulsus in the I. calligraphus aggregation pheromone blend. When ipsdienol was omitted, the trap catches were even lower. However, when lanierone was added to the I. calligraphus bait, significantly more I. avulsus were attracted, and, surprisingly, to an even higher level 
of significance when all three proposed inhibitors to $I$. calligraphus, ipsenol, E-myrcenol, and lanierone, were added to the full blend.

Two species, I. avulsus and I. pini, were found to have very similar aggregation pheromone blends, and their responses were also very similar. Unfortunately, no I. pini was trapped in the $I$. avulsus bioassay, since it was conducted on the coastal plain, outside the range of I. pini. However, large numbers of I. avulsus were trapped in the bioassay for I. pini. In fact, the number of trapped I. avulsus outnumbered the I. pini, 7000 to 900 . The trapping pattern for the I. avulsus beetles is almost identical to the pattern for I. pini in its bioassay, indicating that these two species behave similarly to the compounds tested in this study. In addition, these two species both belong to the avulsus group (group IV) of the genus Ips, according to Hopping [2].

Ips avulsus and I. pini have overlapping ranges only in the southern Appalachians [36, 37], and they may use spatial separations on the host tree. Ips avulsus is usually on the limbs and the top, along with Pityogenes hopkinsi Swaine, and I. pini is usually on the trunk. Neither of these Ips species is attracted to the pheromone of $P$. hopkinsi [38].

4.3. Production of "Inactive Compounds". Why do bark beetles produce compounds not included in their aggregation pheromone? There are different reasons why some compounds identified in male hindgut extracts are not used in their aggregation pheromone. Even though most of the compounds identified in the analyses were monoterpene alcohols, their biosynthetic backgrounds differ. Some are detoxification products of toxic monoterpene hydrocarbons in the host tree resin. Very few detoxification products are used by bark beetles as pheromone components. For Ips beetles only cis-verbenol of all the detoxification products has been proven to be a component of their aggregation pheromones. The presence of this compound is tightly linked to the amount of $(-)-(S)-\alpha$-pinene in the host resin $[39,40]$. The chirality of cis-verbenol in Ips beetles is reported to be the $(-)-(4 S)$-isomer. On the other hand, the $(+)-(R)-$ enantiomer of $\alpha$-pinene is always hydroxylated to $(+)-(4 S)$ trans-verbenol, with no behavioral effect in Ips bark beetles [26]. All other cyclic and bicyclic monoterpene alcohols identified in this study (Table 4) have direct connections to monoterpene hydrocarbons in the host tree resin (Bergquist and Birgersson, unpublished).

On the other hand, the noncyclic monoterpene alcohols identified in this study are not detoxification products of host tree monoterpene hydrocarbons. Instead, geraniol, ipsdienol, ipsenol, and E-myrcenol are all produced de novo through the mevalonic pathway by the beetles [41-43]. The three compounds earlier found to be active in several Ips species are all produced via geraniol as a precursor. While either ipsdienol or ipsenol was found to be active in the species investigated here, no strong activity could be assigned to E-myrcenol, other than reduce attraction of female $I$. grandicollis when omitted (Figure 3(a)), even though it was identified in both I. grandicollis and I. pini. In British Columbia, I. pini were found to produce and use E-myrcenol as a pheromone component $[34,35]$. However, the activity of this compound is still not clear, as trap catches were reduced when it was added to ipsdienol, but attacks increased when the compound was applied to pine logs [35]. It is not known if all populations of $I$. pini produce and are able to perceive E-myrcenol. The southeastern $I$. pini produce $E$ myrcenol, but they apparently do not use it as an aggregation pheromone component. This is probably not a by-product from the production of ipsdienol since I. calligraphus, which produces large amounts of ipsdienol, does not produce any E-myrcenol, while I. grandicollis, which produces ipsenol, was found to also produce $E$-myrcenol.

The small amounts of ipsdienol found in I. grandicollis are probably a by-product from the production of ipsenol, as ipsdienol is supposedly an intermediate between geraniol and ipsenol in the biosynthetic pathway [44]. Besides the noncyclic monoterpene alcohols, the 2-methyl-3-buten-2ol, identified in $I$. avulsus, is also produced de novo via the mevalonic pathway $[45,46]$. This compound was first identified in I. typographus by Bakke et al. [22] and is used by this species as a pheromone component $[10,26]$. The biosynthetic pathway for lanierone is not yet elucidated.

4.4. Chirality of Compounds. Several bioassayed compounds are chiral, that is, having two enantiomeric isomers. Ipsenol and cis-verbenol have been identified as only one enantiomer in Ips bark beetles, (-)-(S)-ipsenol and (-)-(4S)cis-verbenol, and the opposite enantiomers have never been shown to have any effect on the attraction. The chirality of ipsdienol, on the other hand, varies among species and populations within the same species [47, 48]. The chirality of ipsdienol varied between the three species of Ips (Table 5), but no species produced enantiomerically pure ipsdienol, nor did any species have racemic ipsdienol, similar to analyses by Kohnle et al. [49] and Seybold et al. [48]. However, all bioassays were done with racemic ipsdienol. There could have been different trap catches if the enantiomeric composition found in each species had been used in the subtractive assays, but at the time the main focus was to identify which compounds each species used in their aggregation pheromones. We do not think that the opposite enantiomer in the racemic ipsdienol had an inhibitory effect on the response, as none of the species had enantiomeric pure ipsdienol, and I. avulsus, which was farthest from racemic mixture (Table 5), was trapped in very high numbers on I. pini bait (Figure 6). Now that the active pheromone components are identified, the most attractive chiral composition of ipsdienol can be identified.

Ips pini is known to have a wide variation in the chiral composition of ipsdienol between different populations throughout its range $[30,31,50,51]$. There is a correlation between ipsdienol chirality and attractivity of lanierone over the geographic range, with lower response to lanierone with a higher percentage of $(-)-(R)$-ipsdienol. However, more chiral analyses $[50,51]$ than bioassays have been done [52]. California populations of I. pini do not respond to lanierone $[51,52]$. This shift from lanierone as pheromone component 
TABLE 6: Compounds active in field bioassays to four species of Ips, P: produced by males; PC: pheromone component; I: inhibitor.

\begin{tabular}{|c|c|c|c|c|c|c|c|c|c|c|c|c|}
\hline Compound & $\mathrm{P}$ & $\begin{array}{c}\mathrm{PC} \\
\text { grandicollis }\end{array}$ & I & $\mathrm{P}$ & $\begin{array}{c}\text { PC } \\
\text { calligraphus }\end{array}$ & I & $\mathrm{P}$ & $\begin{array}{c}\mathrm{PC} \\
\text { avulsus }\end{array}$ & I & $\mathrm{P}$ & $\begin{array}{l}\text { PC } \\
\text { pini }\end{array}$ & I \\
\hline 232-metylbutenol & & & & & & & $\mathrm{X}$ & $?$ & & & & \\
\hline ipsenol & $\mathrm{X}$ & $\mathrm{X}$ & & & & $\mathrm{X}$ & & & & & & q \\
\hline ipsdienol & & & $\mathrm{X}$ & $\mathrm{X}$ & $\mathrm{X}$ & & $\mathrm{X}$ & $\mathrm{X}$ & & $\mathrm{X}$ & $\mathrm{X}$ & \\
\hline$E$-myrcenol & $\mathrm{X}$ & 우 & & & & & & & & $\mathrm{X}$ & & \\
\hline geraniol & $\mathrm{X}$ & & & $\mathrm{X}$ & & & $\mathrm{X}$ & & & $\mathrm{X}$ & & \\
\hline lanierone & & & $\mathrm{X}$ & & & $\mathrm{X}$ & $\mathrm{X}$ & $\mathrm{X}$ & & $\mathrm{X}$ & $\mathrm{X}$ & \\
\hline cis-verbenol & $\mathrm{X}$ & $\mathrm{X}$ & & $\mathrm{X}$ & $\mathrm{X}$ & & $\mathrm{X}$ & & & $\mathrm{X}$ & $?$ & \\
\hline
\end{tabular}

TABLE 7: Baits suggested for monitoring bark beetles in the genus Ips in southeastern USA.

\begin{tabular}{lc}
\hline I. grandicollis & Ipsenol, cis-verbenol \\
I. calligraphus & Ipsdienol, cis-verbenol \\
I. avulsus and I. pini & Ipsdienol, lanierone \\
\hline
\end{tabular}

is possibly due to a selection pressure by a clerid predator [51].

4.5. Conclusions. Only a few compounds have been identified as aggregation pheromone components in the genus Ips. The four species of Ips in the southeastern USA investigated in this study are no exception, as they share most of their compounds with other species. The production of compounds and their use as pheromone components and/or interspecific inhibitors for each species are summarized in Table 6 . The only species that has a unique compound is $I$. grandicollis, which is the only one of the species studied to use $(-)-(S)$-ipsenol as a pheromone component. Compounds not produced by one species, but by a sympatric species, can act as an interspecific inhibitor. Therefore it is not possible to make a common bait for monitoring populations of the four southern species of Ips. In order to avoid inhibitors, key pheromone components will be left out. If all identified attractants are included, then inhibition for some species will occur.

To monitor the four species of Ips in the southeastern USA, three different baits will be necessary: one for $I$. grandicollis, one for I. calligraphus, and one for both $I$. avulsus and I. pini. These baits (Table 7) will not only be highly attractive to the target species but will also keep the other beetles out, with exception for I. avulsus from the $I$. calligraphus bait.

\section{Acknowledgments}

The authors would like to thank Tim McClure for sorting the trap catches, Bob Larimore, Charles Ford (in memoriam), Fort Benning, and Joe Dinkens, U.S. Forest Service, for providing field sites, Professor Hans Erik Högberg, MidSweden University, for the synthesis of lanierone; and Dr. Dan R. Miller, Dr. Brian T. Sullivan, and Dr. Fredrik Schlyter for reviewing the manuscript. Results from this study were presented at the IUFRO Joint Conference February 6-11, 1994, Maui, Hawaii, and a brief summary was published in the proceedings as G. Birgersson, M. J. Dalusky, and C. W. Berisford in 1995. Interspecific attraction and inhibition among four species of southeastern Ips bark beetles; in F. P. Hain, S. M. Salom, W. F. Ravlin, T. L. Payne, and K. F. Raffa (eds.), Behavior, population dynamics and control of forest insects, proceedings of the IUFRO Joint Conference, February, 1994, pp 12-18. The authors of this paper do not have any financial relation with any commercial identity mentioned in this paper.

\section{References}

[1] S. L. Wood, "The bark and ambrosia beetles of North and Central America (Coleoptera: Scolytidae), a taxonomic monograph," Great Basin Naturalist Memoirs, no. 6, p. 1359, 1982.

[2] G. R. Hopping, "The North American species in groups IV and V of Ips de Geer (Coleoptera: Scolytidae)," Canadian Entomologist, vol. 96, no. 7, pp. 970-978, 1964.

[3] G. R. Hopping, "The North American species in groups IX of Ips de Geer (Coleoptera: Scolytidae)," Canadian Entomologist, vol. 97, no. 4, pp. 422-434, 1965.

[4] G. R. Hopping, "The North American species in groups X of Ips de Geer (Coleoptera: Scolytidae)," Canadian Entomologist, vol. 97, no. 8, pp. 803-809, 1965.

[5] J. H. Borden, "Aggregation pheromones," in Bark Beetles in North American Conifers, J. B. Mitton and K. B. Sturgeon, Eds., 1984.

[6] J. H. Borden, "Aggregation pheromones," in Comprehensive Insect Physiology, Biochemistry, and Pharmacology, G. A. Kerkut and L. I. Gilbert, Eds., 1985.

[7] F. Schlyter and F. G. Birgersson, "Forest beetles," in Pheromones of Non-Lepidopteran Insect Pests of Agricultural Plants, R. J. Hardie and A. K. Minks, Eds., pp. 113-148, CABI Publishers, 2000.

[8] R. M. Silverstein, J. O. Rodin, and D. L. Wood, "Sex attractants in frass produced by male Ips confusus in ponderosa pine," Science, vol. 154, no. 3748, pp. 509-510, 1966.

[9] J. P. Vité, A. Bakke, and J. A. A. Renwick, "Pheromones in Ips (Coleoptera: Scolytidae): occurrence and production," Canadian Entomologist, vol. 104, no. 12, pp. 1967-1975, 1972.

[10] A. Bakke, "Aggregation pheromone in the bark beetle Ips duplicatus," Norwegian Journal of Entomology, vol. 22, no. 1, pp. 67-69, 1975. 
[11] W. Francke, V. Heemann, and B. Gerken, "2 Ethyl 1,6 dioxaspiro[4.4]nonane, principal aggregation pheromone of Pityogenes chalcographus," Naturwissenschaften, vol. 64, no. 11, pp. 590-591, 1977.

[12] J. A. Byers, G. Birgersson, J. Löfqvist, and G. Bergström, "Synergistic pheromones and monoterpenes enable aggregation and host recognition by a bark beetle, Pityogenes chalcographus," Naturwissenschaften, vol. 75, no. 3, pp. 153-155, 1988.

[13] J. A. Byers, F. Schlyter, G. Birgersson, and W. Francke, "E-myrcenol in Ips, duplicatus: an aggregation pheromone component new for bark beetles," Experientia, vol. 46, no. 1112, pp. 1209-1211, 1990.

[14] S. A. Teale, F. X. Webster, A. Zhang, and G. N. Lanier, "Lanierone: a new pheromone component from Ips pini (Coleoptera: Scolytidae) in New York," Journal of Chemical Ecology, vol. 17, no. 6, pp. 1159-1176, 1991.

[15] G. Birgersson and G. Bergström, "Volatiles released from individual spruce bark beetle entrance holes Quantitative variations during the first week of attack," Journal of Chemical Ecology, vol. 15, no. 10, pp. 2465-2483, 1989.

[16] G. Birgersson, F. Schlyter, J. Löfqvist, and G. Bergström, "Quantitative variation of pheromone components in the spruce bark beetle Ips typographus from different attack phases," Journal of Chemical Ecology, vol. 10, no. 7, pp. 1029$1055,1984$.

[17] W. A. Garland and M. L. Powell, "Quantitative selected ion monitoring (QSIM) of drugs and/or drug metabolites in biological matrices," Journal of Chromatographic Science, vol. 19, no. 8, pp. 392-434, 1981.

[18] H. E. M. Dobson, "Analysis of flower and pollen volatiles," in Modern Method of Plant Analysis, Eessential Oils and Waxes, H. F. Linskens and J. F. Jackson, Eds., vol. 12 of New series, Springer, Berlin, Germany, 1991.

[19] W. A. König, R. Krebber, and G. Wenz, "Enantioselective capillary gas chromatography on the basis of host-guest interactions with modified cyclodextrins," High Resolution Chromatography, vol. 12, no. 10, pp. 641-644, 1989.

[20] J. A. Byers, G. Birgersson, J. Löfqvist, M. Appelgren, and G. Bergström, "Isolation of pheromone synergists of bark beetle, Pityogenes chalcographus, from complex insect-plant odors by fractionation and subtractive-combination bioassay," Journal of Chemical Ecology, vol. 16, no. 3, pp. 861-876, 1990.

[21] C. Lejfalk and G. Birgersson, "Wick-baits - a novel delivery system for testing potential semiochemicals," in Proceedings of the 14th Annual Meeting of the International Society of Chemical Ecology, Vancouver, Canada, 1997.

[22] A. Bakke, P. Frøyen, and L. Skattebøl, "Field response to a new pheromonal compound isolated from Ips typographus," Naturwissenschaften, vol. 64, no. 2, pp. 98-99, 1977.

[23] A. Bakke, "The utilization of aggregation pheromone for control of the spruce bark beetle," in Insect Pheromone Technology: Chemistry and application, B. A. Leonhart and M. Beroza, Eds., ACS Symposium Series, no. 190, Washington, DC, USA, 1982.

[24] A. Bakke, "The recent Ips typographus outbreak in Norway experiences from a control program," Holarctic Ecology, vol. 12, no. 4, pp. 515-519, 1989.

[25] J. P. Vite, "The European struggle to control Ips typographus: past, present and future," Holarctic Ecology, vol. 12, no. 4, pp. 520-525, 1989.

[26] F. Schlyter, G. Birgersson, J. A. Byers, J. Löfqvist, and G. Bergström, "Field response of spruce bark beetle, Ips typographus, to aggregation pheromone candidates," Journal of Chemical Ecology, vol. 13, no. 4, pp. 701-716, 1987.
[27] J. A. A. Renwick, G. B. Pitman, and J. P. Vité, "2-Phenylethanol isolated from bark beetles," Die Naturwissenschaften, vol. 63, no. 4, p. 198, 1976.

[28] N. Tomescu, B. B. Kis, I. Opreanu, and L. Tautan, "Modifications of the response of Ips typographus (Coleoptera: Scolytidae) to the aggregation pheromone in mixture with other substances," Revue Roumaine de Biologie Serie de Biologie Animale, vol. 27, no. 1, pp. 77-80, 1982.

[29] D. S. Pureswaran, R. Gries, J. H. Borden, and H. D. Pierce, "Dynamics of pheromone production and communication in the mountain pine beetle, Dendroctonus ponderosae Hopkins, and the pine engraver, Ips pini (Say) (Coleoptera: Scolytidae)," Chemoecology, vol. 10, no. 4, pp. 153-168, 2000.

[30] F. Schlyter, J. Lofqvist, and J. A. Byers, "Behavioural sequence in the attraction of the bark beetle Ips typographus to pheromone sources," Physiological Entomology, vol. 12, no. 2, pp. 185-196, 1987.

[31] J. C. Dickens, "Behavioural and electrophysiological responses of the bark beetle, Ips typographus, to potential pheromone components," Physiological Entomology, vol. 6, no. 3, pp. 251261, 1981

[32] M. C. Birch, D. M. Light, D. L. Wood et al., "Pheromonal attraction and allomonal interruption of Ips pini in California by the two enantiomers of Ipsdienol," Journal of Chemical Ecology, vol. 6, no. 3, pp. 703-717, 1980.

[33] G. N. Lanier, A. Classon, T. Stewart, J. J. Piston, and R. M. Silverstein, "Ips pini: the basis for interpopulational differences in pheromone biology," Journal of Chemical Ecology, vol. 6, no. 3, pp. 677-687, 1980.

[34] G. Gries, H. D. Pierce Jr., B. S. Lindgren, and J. H. H. Borden, "New techniques for capturing and analyzing semiochemicals for scolytid beetles (Coleoptera: Scolytidae)," Journal of Economic Entomology, vol. 81, no. 6, pp. 1715-1720, 1988.

[35] D. R. Miller, G. Gries, and J. H. Borden, "E-myrcenol: a new pheromone for the pine engraver, Ips pini (Say) (Coleoptera: Scolytidae)," Canadian Entomologist, vol. 122, no. 5-6, pp. 401-406, 1990.

[36] D. R. Miller, C. Asaro, and C. W. Berisford, "Attraction of southern pine engravers and associated bark beetles (Coleoptera: Scolytidae) to Ipsenol, Ipsdienol, and lanierone in Southeastern United States," Journal of Economic Entomology, vol. 98, no. 6, pp. 2058-2066, 2005.

[37] USDA Forest, "Insects of eastern conifers," USDA Forest Service Miscellaneous Publications, no. 1426. 1985.

[38] G. Birgersson, M. J. Dalusky, and C. W. Berisford, "Identification of an aggregation pheromone for Pityogenes hopkinsi (Coleoptera: Scolytidae)," Canadian Entomologist, vol. 132, no. 6, pp. 951-963, 2000.

[39] D. Klimetzek and W. Francke, "Relationship between the enantiomeric composition of $\alpha$-pinene in host trees and the production of verbenols in Ips-species," Experientia, vol. 36, no. 12, pp. 1343-1345, 1980.

[40] M. Lindström, T. Norin, G. Birgersson, and F. Schlyter, "Variation of enantiomeric composition of $\alpha$-pinene in norway spruce, Picea abies, and its influence on production of verbenol isomers by Ips typographus in the field," Journal of Chemical Ecology, vol. 15, no. 2, pp. 541-548, 1989.

[41] P. Ivarsson, F. Schlyter, and G. Birgersson, "Demonstration of de novo pheromone biosynthesis in Ips duplicatus (Coleoptera: Scolytidae): inhibition of Ips dienol and E-Myrcenol production by compactin," Insect Biochemistry and Molecular Biology, vol. 23, no. 6, pp. 655-662, 1993.

[42] P. Ivarsson and G. Birgersson, "Regulation and biosynthesis of pheromone components in the double spined bark beetle 
Ips duplicatus (Coleoptera: Scolytidae)," Journal of Insect Physiology, vol. 41, no. 10, pp. 843-849, 1995.

[43] S. J. Seybold, D. R. Quilici, J. A. Tillman, D. Vanderwel, D. L. Wood, and G. J. Blomquist, "De novo biosynthesis of the aggregation pheromone components Ips enol and Ips dienol by the pine bark beetles Ips paraconfusus lanier and Ips pini (Say) (Coleoptera: Scolytidae)," Proceedings of the National Academy of Sciences of the United States of America, vol. 92, no. 18, pp. 8393-8397, 1995.

[44] R. H. Fish, L. E. Browne, D. L. Wood, and L. B. Hendry, "Pheromone biosynthetic pathways: conversions of deuterium labelled Ips dienol with sexual and enantioselectivity in Ips paraconfusus lanier," Tetrahedron Letters, vol. 20, no. 17, pp. 1465-1468, 1979.

[45] B. S. Lanne, P. Ivarsson, P. Johnsson, G. Bergström, and A. B. Wassgren, "Biosynthesis of 2-methyl-3-buten-2-ol, a pheromone component of Ips typographus (Coleoptera: Scolytidae)," Insect Biochemistry, vol. 19, no. 2, pp. 163-167, 1989.

[46] P. Ivarsson, The pheromone systems of the spruce bark beetles, Ips duplicatus and I. typographus: biosynthesis and regulations, Ph.D. thesis, Göteborg University, Sweden, 1995.

[47] S. Seybold, The role of chirality in the olfactory-directed aggregation behavior of pine engraver beetles in the genus Ips (Coleoptera: Scolytidae), Ph.D. thesis, Department of Entomology, University of California, Berkeley, Calif, USA, 1992.

[48] S. J. Seybold, T. Ohtsuka, D. L. Wood, and I. Kubo, "Enantiomeric composition of Ips dienol: a chemotaxonomic character for north American populations of Ips spp. in the Ips subgeneric group (coleoptera: Scolytidae)," Journal of Chemical Ecology, vol. 21, no. 7, pp. 995-1016, 1995.

[49] U. Kohnle, J. P. Vite, H. Meyer, and W. Francke, "Response of 4 American engraver bark beetles, Ips spp. (Col, Scolytidae), to synthetic racemates of chiral pheromones," Journal of Applied Entomology, vol. 117, no. 5, pp. 451-456, 1994.

[50] D. R. Miller, J. H. Borden, and K. N. Slessor, "Enantiospecific pheromone production and response profiles for populations of pine engraver, Ips pini (Say) (Coleoptera: scolytidae), in British Columbia," Journal of Chemical Ecology, vol. 22, no. 11, pp. 2157-2172, 1996.

[51] S. J. Seybold, S. A. Teale, D. L. Wood et al., "The role of lanierone in the chemical ecology of Ips pini (Coleoptera: Scolytidae) in California," Journal of Chemical Ecology, vol. 18, no. 12, pp. 2305-2329, 1992.

[52] D. R. Miller, K. E. Gibson, K. F. Raffa, S. J. Seybold, S. A. Teale, and D. L. Wood, "Geographic variation in response of pine engraver, Ips pini, and associated species to pheromone, lanierone," Journal of Chemical Ecology, vol. 23, no. 8, pp. 2013 2031, 1997. 

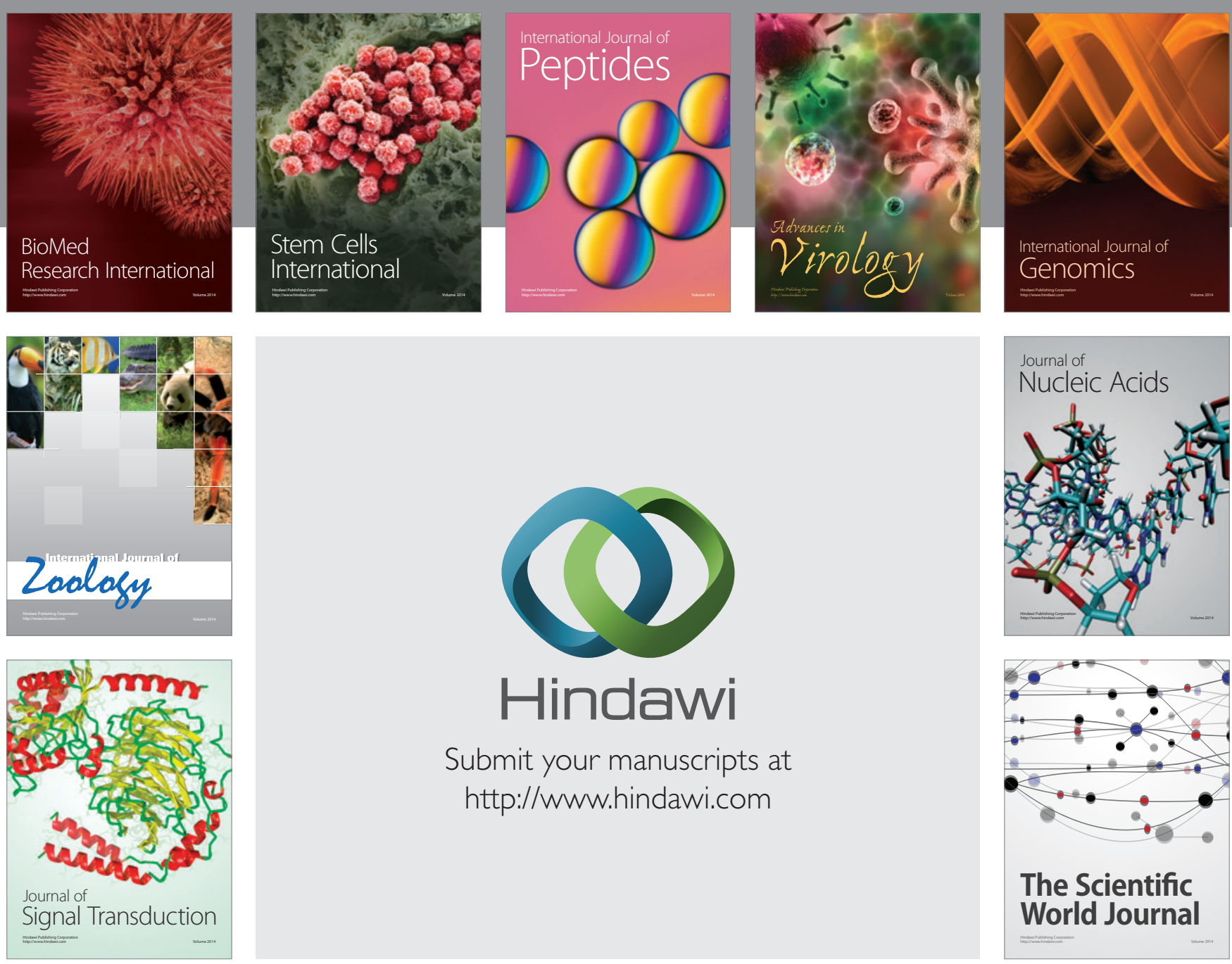

Submit your manuscripts at

http://www.hindawi.com
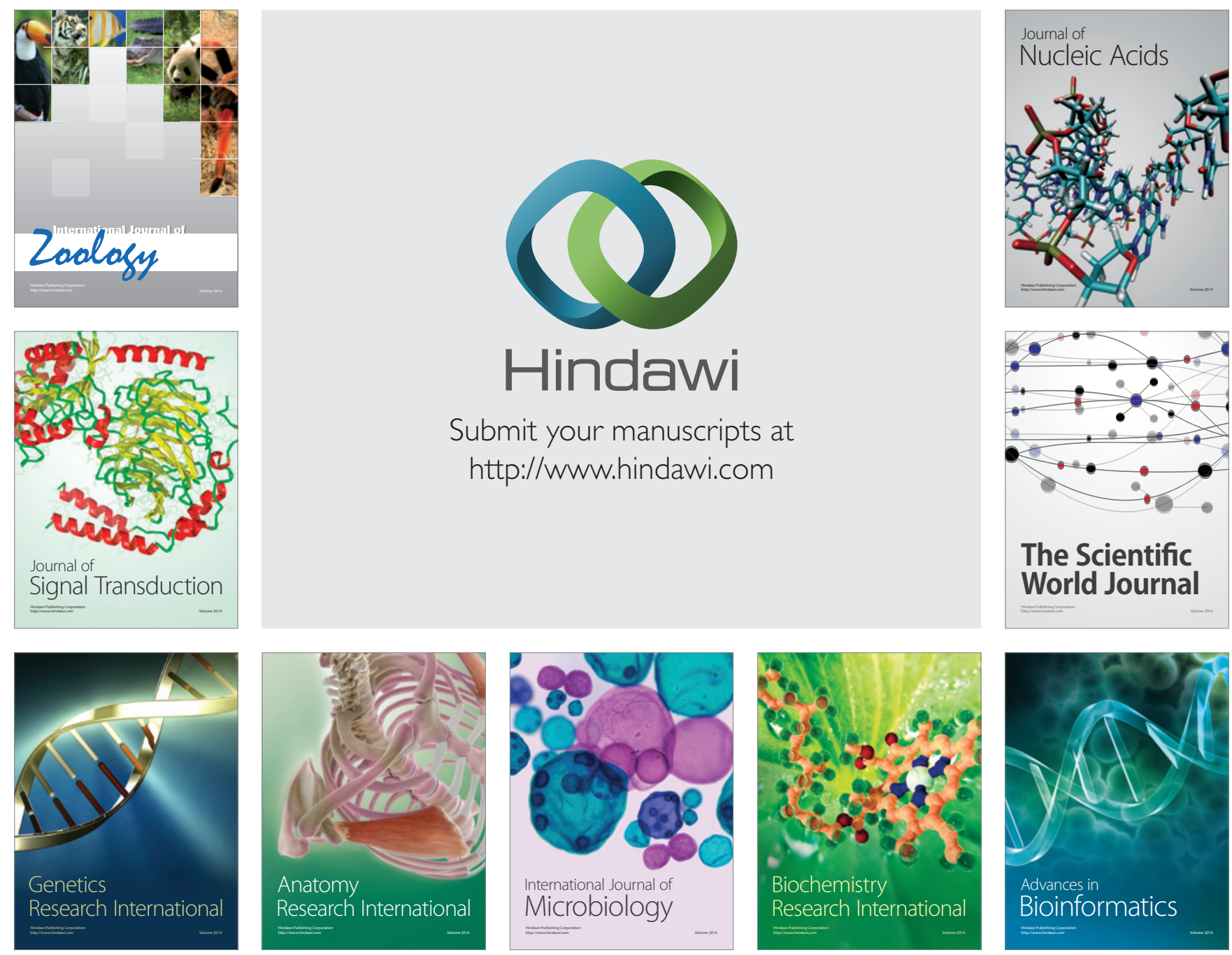

The Scientific World Journal
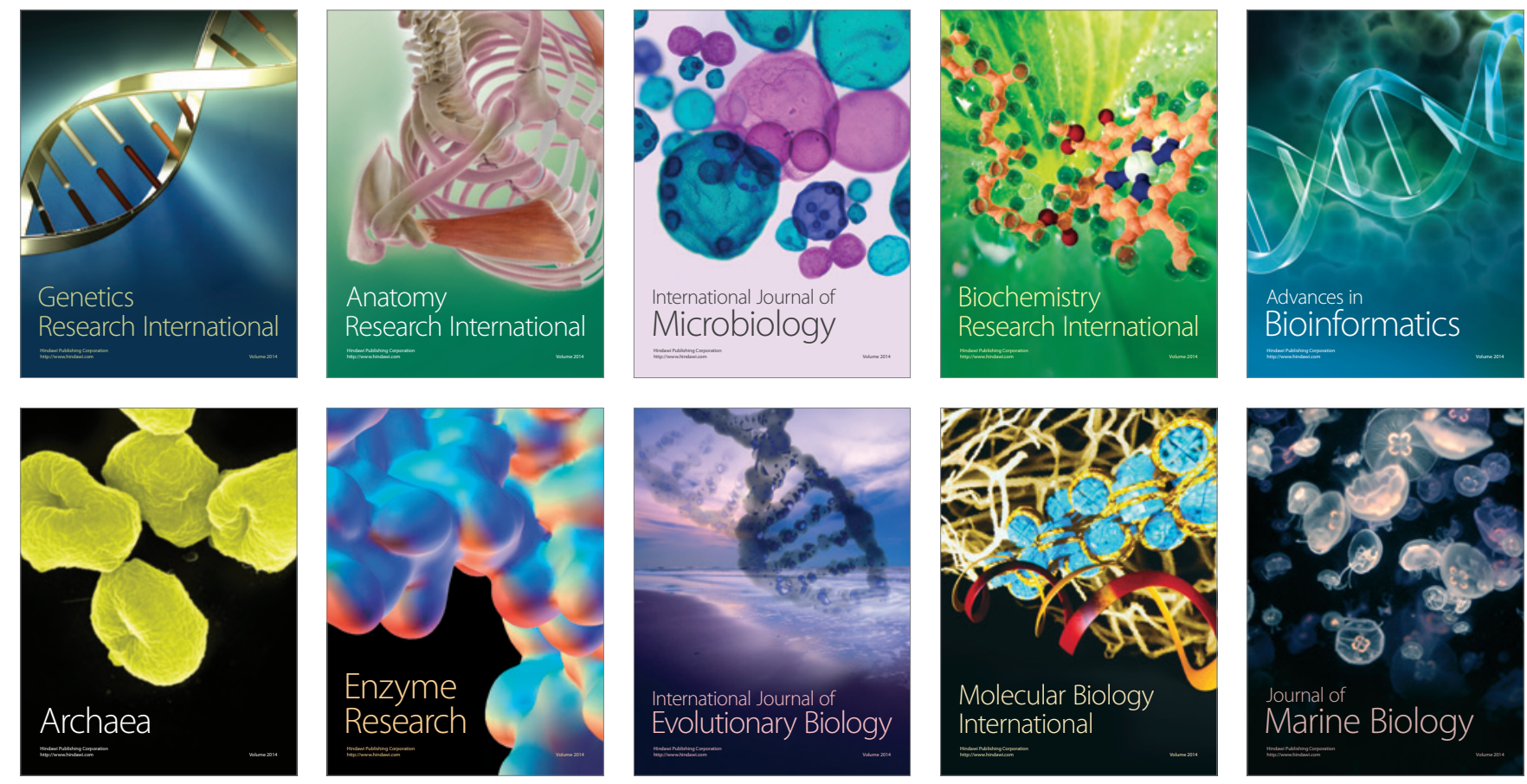